\title{
Corrigendum: Modulation of Type III Secretion System in Pseudomonas aeruginosa: Involvement of the PA4857 Gene Product
}

\author{
Miao Zhu ${ }^{1}$, Jingru Zhao ${ }^{1}$, Huaping Kang ${ }^{1}$, Weina Kong ${ }^{1}$, Yuanyu Zhao ${ }^{2}$, Min $W u^{2}$ and \\ Haihua Liang ${ }^{1 *}$ \\ ${ }^{1}$ Key Laboratory of Resources Biology and Biotechnology in Western China, Ministry of Education, Department of Life \\ Science, Northwest University, Xi'an, China, ${ }^{2}$ Department of Basic Science, School of Medicine and Health Science, \\ University of North Dakota, Grand Forks, ND, USA
}

Keywords: type III secretion system, tspR, bacterial virulence, regulatory mechanisms, Pseudomonas aeruginosa

\section{A corrigendum on}

OPEN ACCESS

Edited by:

Yuji Morita,

Aichi Gakuin University, Japan

Reviewed by:

Gilbert Greub,

University of Lausanne, Switzerland

*Correspondence: Haihua Liang

lianghh@nwu.edu.cn

Specialty section: This article was submitted to

Infectious Diseases,

a section of the journa

Frontiers in Microbiology

Received: 15 April 2016

Accepted: 25 May 2016

Published: 07 June 2016

Citation:

Zhu M, Zhao J, Kang H, Kong W, Zhao Y, Wu M and Liang H (2016) Corrigendum: Modulation of Type III Secretion System in Pseudomonas aeruginosa: Involvement of the PA4857 Gene Product. Front. Microbiol. 7:881. doi: 10.3389/fmicb.2016.00881
Modulation of Type III Secretion System in Pseudomonas aeruginosa: Involvement of the PA4857 Gene Product

by Zhu, M., Zhao, J., Kang, H., Kong, W., Zhao, Y., Wu, M., and Liang, H. (2016). Front. Microbiol. 7:7. doi: 10.3389/fmicb.2016.00007

Due to an oversight, in the original article Min $\mathrm{Wu}$ and Yuanyu Zhao were not included in the author list. They have now been added and the correct author list can be found above. We have also updated the Acknowledgements section to reflect the financial support received by these two authors.

The correction does not affect the scientific validity of the results.

The original article has been updated.

\section{ACKNOWLEDGMENTS}

The financial support for animal work was supported by the US National Institute of Health grant (AI109317-01), UND SMHS, and Northwest University funding (338050069). The UND IACUC committee (Approval \#:1204-4) and Northwest University have approved the protocols that allowed for the performing of animal experiments.

Conflict of Interest Statement: The authors declare that the research was conducted in the absence of any commercial or financial relationships that could be construed as a potential conflict of interest.

Copyright $\odot 2016$ Zhu, Zhao, Kang, Kong, Zhao, Wu and Liang. This is an open-access article distributed under the terms of the Creative Commons Attribution License (CC BY). The use, distribution or reproduction in other forums is permitted, provided the original author(s) or licensor are credited and that the original publication in this journal is cited, in accordance with accepted academic practice. No use, distribution or reproduction is permitted which does not comply with these terms. 